\title{
COVID-19 Pandemic and Climate Change Crisis: A Systemic Review
}

\author{
Ashekur Rahman Mullick ${ }^{1}$, Irin Hossain ${ }^{2 *}$, Mohammad Tahsin Islam ${ }^{3}$ \\ ${ }^{1}$ Delta Medical College and Hospital, Dhaka, Bangladesh \\ ${ }^{2}$ National Institute of Preventive and Social Medicine, Dhaka, Bangladesh \\ ${ }^{3}$ Gerico France \\ * Corresponding Author: irin.hossain@gmail.com
}

\begin{abstract}
This review study aims at discussing about the linkage between health and the environment. Climate change and the loss of biodiversity can stimulate illnesses to spread. Long-term exposure of air pollutants cause chronic lung and heart diseases that make viruses like COVID-19 even more dangerous. The need for more natural resources has forced humans to encroach on various natural habitats and expose themselves to yet unknown pathogens which is responsible for COVID-19 and other outbreaks. Lockdowns across the world due to prevent the COVID-19 transmission have already resulted in a significant drop in greenhouse gas emissions and pollutants. In China, for instance, the lockdown caused carbon dioxide to drop by at least 25 percent and nitrogen dioxide by 37 percent. It was a systemic review study regarding the relationship between COVID-19 and climate change. We gather total 16 articles and newsletters related to COVID-19 and climate change using different search portal like PubMed, Google Scholar, Nature, and Lancet. After proper review only 12 articles which were related to this study were taken for this systemic review purpose. Although both COVID-19 and climate change have proven to be deadly for humans, governments of different countries haven't seen them as separate and unconnected phenomena and have therefore responded collectively to them.
\end{abstract}

Keywords: COVID-19, Pandemic, Climate Change.

\section{Introduction}

Diseases that originate in animals, like Ebola or COVID-19 will become more widespread as climate change makes larger areas warm. ${ }^{1}$ there is no direct evidence that climate change is influencing the spread of COVID-19, but it is true that climate change alters the relation between human and other species on Earth which causes increase risk for infections.

Due to increase temperature of planate earth, both big and small animals, on land and in the sea, are headed to the poles to get out of the increased temperature. That means animals are coming into contact with other animals they normally wouldn't, and that creates an opportunity for pathogens to transmit into new hosts.

Many of the root causes of climate change also increase the risk of pandemics. Deforestation, which occurs mostly for agricultural purposes, is the largest cause of habitat loss worldwide. Loss of habitat forces animals to migrate and potentially contact other animals or people and share germs.
Large livestock farms can also serve as a source for spillover of infections from animals to people. Less demand for animal meat and more sustainable animal husbandry could decrease emerging infectious disease risk and lower greenhouse gas emissions. ${ }^{2}$

\section{Materials and Methods}

It was a systemic review study regarding the relationship between COVID-19 and climate change. We gather total 16 articles and newsletters related to COVID-19 and climate change using different search portal like PubMed, Google Scholar, Nature, and Lancet. After proper literature review only 12 articles and newsletters which were related to this study were taken for this systemic review purpose.

\section{Results}

According to a report by Global Landscape News, from February 3 to March $1, \mathrm{CO}_{2}$ emissions were down by at least $25 \%$ because of the measures to contain the coronavirus. As the world's biggest polluter, China contributes $30 \%$ 
of the world's $\mathrm{CO}_{2}$ emissions annually, so the impact of this kind of drop is huge, even over a short period. ${ }^{1}$

According to Council on Foreign Relation, during a four-week period beginning in February, China, the world's largest emitter, saw its emissions fall by 25 percent. Since the start of the Lunar New Year, China's six largest power plants have experienced a 40 percent reduction in coal consumption compared to the last quarter of 2019.

In Europe, the daily carbon emissions of the European Union's twenty-seven member states have fallen by 58 percent since the implementation of strict measures to curb the pandemic, including nationwide lockdowns.

In the United States, the world's second largest emitter, the Energy Information Agency has predicted that national energy-related carbon dioxide emissions will fall by 7.5 percent in 2020 , compared to a decrease of 2.7 percent in 2019 . Researchers have determined that carbon monoxide emissions in New York City have dropped by almost 50 percent compared to last year. $^{2}$

In a study entitled "Human Health: Ecosystem Regulation of Infectious Diseases Coordinating" in 2015, showed the mechanisms of potential changing incidence as related to ecosystem changes due to various types of infection diseases which were enlisted in table $1 .^{3}$

In a study on 2008 entitled "Climate Change: Impact on Viral Diseases" showed the impact of climate change of virus infections including various types of respiratory infection which is shown in Table $2{ }^{4}$

This same study showed that, Severe Acute Respiratory Syndrome (SARS) could reemerge. This coronavirus from Asia provoked severe acute pneumonia in 2003. Close contacts between humans and Chinese animals (wild civets sold in rural markets, bats) could be the source of the epidemics. In case of climate disasters, favored by globalization with worldwide trip facilities, the diffusion of this pathogenic agent, which quickly travelled from Guangzhong to Hong Kong and to Toronto in the past, could be recurrent. ${ }^{4}$

A report by The Guardian view on the climate and coronavirus: global warnings showed that $18 \%$ in China between February and March; between $40 \%$ and $60 \%$ over recent weeks in
Europe. Habits and behaviors once regarded as sacrosanct have been turned on their heads: road traffic in the UK has fallen by $70 \%$. Global air traffic has halved. Meanwhile, a much-needed spotlight has been thrown on humans' troubling relationship to wildlife, with some experts arguing that the degradation of the natural world and exploitation of other species is among the pandemic's causes. ${ }^{5}$

\section{Discussion}

The coronavirus pandemic is a crisis for all and its consequences will be felt for a long run. Global health conditions will eventually return to a form of normal, but unfortunately environment will never do so. World's climate has irreversibly changed. The average global temperature has already risen by $1^{\circ} \mathrm{C}$. As the covid- 19 pandemic is painfully showing, challenges are increasingly global in nature and require systemic solutions. To control the coronavirus, governments have needed to mandate social distancing, ground aero planes and close borders. For climate change, they need to back clean technologies and end subsidies to polluting industries. ${ }^{6}$

\section{Air pollution and COVID-19}

People who are exposed to more air pollution and who smoke are going to fare worse if infected with COVID-19 than those who are breathing cleaner air, and who don't smoke.

Air pollution is strongly associated with people's risk of getting pneumonia and other respiratory infections. ${ }^{7}$

Researchers at the Harvard TH Chan School of Public Health in Boston, analysed air pollution and Covid-19 deaths up to 4 April in 3,000 US counties, covering $98 \%$ of the population and found that an increase of only $1 \mu \mathrm{g} / \mathrm{m} 3$ in PM2.5 [particles] is associated with a $15 \%$ increase in the Covid-19 death rate. ${ }^{8}$

Northern Italy was one of Europe's most air polluted areas and that the death rate reported up to 21 March in the northern Lombardy and Emilia-Romagna regions was about $12 \%$, compared with $4.5 \%$ in the rest of Italy. ${ }^{8}$

\section{Temperature variation and COVID-19}

According to an early analysis by scientists at the Massachusetts Institute of Technology, Communities living in warmer places appear to have a comparative advantage to slow the 
transmission of coronavirus infections. Most coronavirus transmissions had occurred in regions with low temperatures, between 37.4 and 62.6 degrees Fahrenheit (or 3 and 17 degrees Celsius). The four types of coronavirus that cause the common cold every year also wane in warmer weather. ${ }^{9}$

Sars-Cov-2 can survive for up to 72 hours on hard surfaces like plastic and stainless steel at temperatures of between 21-23C (70-73F) and in relative humidity of $40 \%$. Exactly how the Covid19 virus behaves at other temperatures and humidity has still to be tested, but research on other coronaviruses suggests they can survive for more than 28 days at $4 \mathrm{C} .^{10}$

\section{Lockdown due to COVID-19 and climate change}

Air is a little bit cleaner as COVID-19 shutdown decrease in pollutants such as nitrogen dioxide, a gas emitted by motor vehicles, power plants, and industrial facilities. During the third and fourth weeks of March, when California announced and then implemented state-wide "shelter in place" orders, there was a statistics of decreasing nitrogen dioxide amount in air.

Lockdowns across the world have already resulted in a significant drop in greenhouse gas emissions and pollutants. In China, for instance, the lockdown caused carbon dioxide to drop by at least 25 percent and nitrogen dioxide by 37 percent.

Concentrations of carbon dioxide, the gas that's most responsible for trapping heat in Earth's atmosphere, are up from 413 ppm this time last year to $416 \mathrm{ppm}$ now. That's because on average, a carbon dioxide molecule will remain in the atmosphere for about four years. Then, when they leave the atmosphere, the carbon dioxide molecules simply swap places with carbon dioxide in the ocean, which means the extra carbon dioxide we've added to our atmosphere from burning fossil fuels for decades will remain in our environment for centuries. ${ }^{11}$

\section{Rainfall pattern and COVID-19}

Some coronaviruses can survive in water for up to two days, meaning that heavy rain may have lifted the virus off some surfaces only to deposit it onto others and causes more transmission. Heavy showers will dislodge the virus that is 'hanging in the air' and wash it away to the sea. ${ }^{12}$

\section{Conclusion}

Moments of crisis are always moments of opportunity. Many crucial decisions will be made over the next few months. As options are considered, we should ask ourselves what is the most effective way to overcome the immediate threat and how to dovetail those decisions into the making of a future where we not only survive, but actually thrive together with nature.

\section{Recommendations}

1. As the covid-19 pandemic is painfully showing, our challenges are increasingly global in nature and require systemic solutions.

2. To control the coronavirus, governments have needed to mandate social distancing, ground aero planes and close borders. For climate change, they need to back clean technologies and end subsidies to polluting industries.

3. Emissions from every country accumulate in the atmosphere independently of where they are released. Therefore cuts will only be effective if all nations are on the same trajectory - towards net-zero emissions by 2050.

4. According to WHO, by reducing the environmental and social risk factors people are exposed to, nearly a quarter of the global health burden (measured as loss from sickness, death and financial costs) could be prevented.

5. Reducing air pollution also helps keep our lungs healthy, which can protect us from respiratory infections like coronavirus. 
Figures and Tables

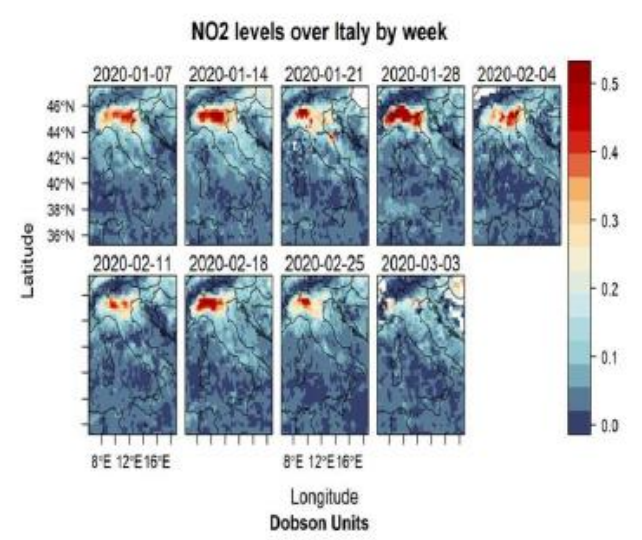

Figure 1. $\mathrm{NO}_{2}$ levels over Italy by week

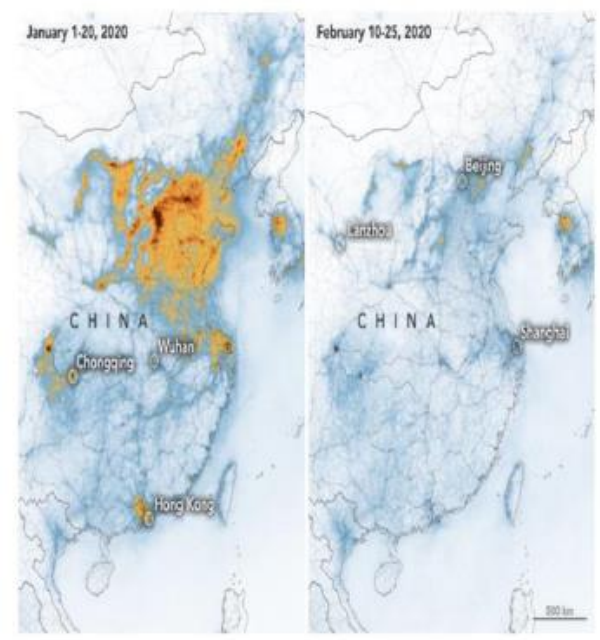

Figure 2. Improve air quality in China due to lockdown

Table 1. Mechanisms of potential changing incidence as related to ecosystem changes due to various types of infection diseases

\begin{tabular}{|l|l|l|l|l|l|}
\hline Disease & $\begin{array}{l}\text { Cases per } \\
\text { Year }\end{array}$ & $\begin{array}{l}\text { Emergence } \\
\text { Mechanism }\end{array}$ & $\begin{array}{l}\text { Anthropogenic } \\
\text { Drivers }\end{array}$ & $\begin{array}{l}\text { Geographical } \\
\text { Distribution }\end{array}$ & $\begin{array}{l}\text { Expected } \\
\text { Variation } \\
\text { from } \\
\text { Ecological } \\
\text { Change }\end{array}$ \\
\hline HIV & 42 million & host transfer & $\begin{array}{l}\text { forest } \\
\text { encroachment; } \\
\text { bush meat } \\
\text { hunting; } \\
\text { human } \\
\text { behaviour }\end{array}$ & global & Low \\
\hline Hantavirus & 200,000 & $\begin{array}{l}\text { variations in } \\
\text { population } \\
\text { density of } \\
\text { vaturability } \\
\text { varal food } \\
\text { sources }\end{array}$ & & Moderate \\
\hline
\end{tabular}




\begin{tabular}{|c|c|c|c|c|c|}
\hline Rabies & $\begin{array}{l}35,000 \\
\text { deaths }\end{array}$ & $\begin{array}{l}\text { biodiversity } \\
\text { loss, } \\
\text { altered host } \\
\text { selection }\end{array}$ & $\begin{array}{l}\text { deforestation } \\
\text { and mining }\end{array}$ & tropical & Moderate \\
\hline SARS & $\begin{array}{l}8,098 \text { (From } \\
\text { November } \\
2002 \text { to July } \\
2003, \\
\text { probable } \\
\text { cases of } \\
\text { SARS } \\
\text { reported to } \\
\text { the World } \\
\text { Health } \\
\text { Organization) }\end{array}$ & host transfer & $\begin{array}{l}\text { intensive } \\
\text { livestock } \\
\text { operations } \\
\text { mixing wild } \\
\text { and domestic } \\
\text { animals }\end{array}$ & global & Low \\
\hline Cholera & ----- & $\begin{array}{l}\text { sea surface } \\
\text { temperature } \\
\text { rising }\end{array}$ & $\begin{array}{l}\text { climate } \\
\text { variability and } \\
\text { change }\end{array}$ & $\begin{array}{l}\text { global } \\
\text { (tropical) }\end{array}$ & Moderate \\
\hline Ebola & $\begin{array}{l}----- \\
\end{array}$ & $\begin{array}{l}\text { forest } \\
\text { encroachment; } \\
\text { bush meat } \\
\text { hunting }\end{array}$ & $\begin{array}{l}\text { forest } \\
\text { encroachment }\end{array}$ & Africa & Low \\
\hline $\begin{array}{l}\text { Nipah/Hendra } \\
\text { viruses }\end{array}$ & $\begin{array}{l}----- \\
\end{array}$ & niche invasion & $\begin{array}{l}\text { industrial food } \\
\text { production; } \\
\text { deforestation; } \\
\text { climate } \\
\text { abnormalities }\end{array}$ & $\begin{array}{l}\text { Australia; } \\
\text { Southeast } \\
\text { Asia }\end{array}$ & High \\
\hline COVID-19 & $\begin{array}{l}1,876,373 \\
\text { (Till 13 } \\
\text { April, 2020) }\end{array}$ & host transfer & $\begin{array}{l}\text { intensive } \\
\text { livestock } \\
\text { operations } \\
\text { mixing wild } \\
\text { and domestic } \\
\text { animals } \\
\end{array}$ & global & High \\
\hline
\end{tabular}

Figure 2. Climate Change and Health Impact

\begin{tabular}{|l|l|}
\hline Change & Adverse Effects \\
\hline More very hot days, allergens & More deaths \\
\hline $\begin{array}{l}\text { Warming temperatures/ } \\
\text { rainfall/ conditions favouring } \\
\text { insects proliferation }\end{array}$ & $\begin{array}{l}\text { Vector-borne infections: } \\
\text { Arbo viruses, malaria }\end{array}$ \\
\hline Floods & $\begin{array}{l}\text { Movement of people/crowding } \\
\text { - more infectious diseases } \\
\text { - water-borne infection } \\
\text { enteric viruses, cholera }\end{array}$ \\
\hline $\begin{array}{l}\text { Decrease in crop yields, } \\
\text { in fisheries } \\
\text { Sea-level rise }\end{array}$ & $\begin{array}{l}\text { Movement of people/crowding } \\
\text { viral gastroenteritis } \\
\text { viral respiratory epidemics }\end{array}$ \\
\hline
\end{tabular}




\section{References}

[1]. How coronavirus could swing the battle against Climate change: The Global Landscape News. Date of access: 02/04/2020 Available at:

https://news.globallandscapesforum.org/43120/8-

reads-on-how-coronavirus-could-swing-the-battleagainst-climate-change/.

[2]. What the Coronavirus Pandemic Teaches Us About Fighting Climate Change: Council on Foreign Relation. Date off access: 10/04/2020 Available at: https://www.cfr.org/in-brief/what-coronaviruspandemic-teaches-us-about-fighting-climate-change.

[3]. Felix P. Amerasinghe, Kaw Bing Chua, Peter Daszak, Alex D. Hyatt, David Molyneux, Madeleine Thomson, Dr. Laurent Yameogo, MweleceleMalecela-Lazaro, Pedro Vasconcelos, Yasmin RubioPalis, Diarmid Campbell-Lendrum, Thomas Jaenisch, Hassane Mahamat, Cliffor CW. Human Health: Ecosystem Regulation of Infectious Diseases Coordinating. Indian Journal of Trait Knowledge. 2015; 14(1):69-75.

[4]. Schvoerer E, Massue J-P, Gut J-P, Stoll-Keller F. Climate Change: Impact on Viral Diseases. Open Epidemiol J. 2008; 1(1):53-6.

[5]. The Guardian view on the climate and Coronavirus: global warnings: The Guardian. Access on: $\quad 12 / 04 / 2020$. Available on: https://www.theguardian.com/commentisfree/2020/a $\mathrm{pr} / 12 /$ the-guardian-view-on-the-climate-andcoronavirus-global-warnings.

[6]. Our approach to covid-19 can also help tackle Climate change: The Daily Newsletter. Date of access: 08/04/2020 Available at: https://www.newscientist.com/article/mg24532763500-our-approach-to-covid-19-can-also-help-tackleclimate-change/\#ixzz6J2NJuoPs.
[7]. Coronavirus, climate change, and the environment: The Environmental Health News. Date of access: 03/04/2020 Available at: https://www.ehn.org/coronavirus-environment2645553060.html.

[8]. Air pollution linked to far higher Covid-19 death rates, study finds: The Guardian. Date of access: 08/04/2020 Available at: https://www.theguardian.com/environment/2020/apr/ 07/air-pollution-linked-to-far-higher-covid-19-deathrates-study-finds.

[9]. Warmer Weather May Slow, but Not Halt, Coronavirus: The New York Times, Date of access: 25/03/2020 Available at: https://www.nytimes.com/2020/03/22/health/warmweather-coronavirus.html.

[10]. Will warm weather really kill off Covid-19?: The BBC, Date of access: 28/03/2020 Available at: https://www.bbc.com/future/article/20200323coronavirus-will-hot-weather-kill-covid-19.

[11]. Sorry, Climate Change Hasn't Gone Away Just Because Of COVID-19: The Forbes, Date of access: 08/04/2020 Available at: https://www.forbes.com/sites/lauratenenbaum/2020/0 4/06/sorry-climate-change-hasnt-gone-away-justbecause-of-covid-

19/?fbclid=IwAR0mAbAx5_Ie7dJlfFnec6fIeHKdUtSFr4SIbtOyhdPTpyDwLFdTTJOXfI\#64c4f5 b84e7b.

[12]. Rain and cloud seeding in the UAE: It might actually help prevent the spread of coronavirus: The Gulf news. Date of access: 07/04/2020 Available at: https://gulfnews.com/uae/rain-and-cloud-seeding-inthe-uae-it-might-actually-help-prevent-the-spread-ofcoronavirus-heres-how-1.1584870653388. 